\title{
First Record of Dinoponera lucida (Hymenoptera: Formicidae), in the Northeast Region of the State of Minas Gerais, Brazil
}

\author{
Primeiro Registro de Dinoponera lucida (Hymenoptera: Formicidae), na Região Nordeste do \\ Estado de Minas Gerais, Brasil
}

\author{
Douglas Silva Parreira*a; Lorena Duarte Batista ${ }^{\mathrm{b}}$; Humberto Correa Bonfim Ribeiro ${ }^{\mathrm{c}}$; Maira Parreira Alves Coelho ${ }^{\mathrm{a}}$ \\ ${ }^{a}$ Universidade Federal de Viçosa, Programa de Pós-Graduação Stricto Sensu em Fitotecnia. MG, Brasil. \\ ${ }^{b}$ Centro Universitário do Leste de Minas Gerais, Coronel Fabriciano. MG, Brasil. \\ ${ }^{\mathrm{c}}$ Fundação Educacional de Caratinga. MG, Brasil. \\ *E-mail: douglasparreira@ig.com.br
}

\begin{abstract}
Dinoponera lucida is an endemic ant to the Atlantic Forest and since 2003 has been on the list of endangered species. The objective of this research was to report the occurrence of this ant in area under anthropic action in the Jequitinhonha Valley, Minas Gerais, Brazil, outside its known geographic distribution area. Fifty ants were collected and taken to the Biological Control Laboratory of Insects in Viçosa, Minas Gerais State, Brazil, placed in $70 \%$ alcohol and sent to the Federal Institute of Espirito Santo, Brazil to be identified. Maps were elaborated to illustrate the distance from the collection point of the D. lucida specimens to their geographic distribution and the survey of the predominant vegetation of the municipality of Ponto dos Volantes. This is the first report of $D$. lucida in the north of Minas Gerais State, Brazil. Most individuals of $D$. lucida were dead or broken, but possible causes such as the destruction of their habitat or competition were not determined. The presence of this ant outside its original endemic area indicates the possible presence of isolated populations of $D$. lucida.
\end{abstract}

Keyword: Adaptation. Ant. Atlantic Forest. Fragmentation. Insects.

\section{Resumo}

Dinoponera lucida é uma formiga endêmica da Mata Atlântica e desde 2003 está na lista de espécies ameaçadas de extinção. O objetivo dessa pesquisa foi relatar a ocorrência desta formiga em uma área sob ação antrópica no Vale do Jequitinhonha, Minas Gerais, Brasil, fora da sua área de distribuição geográfica conhecida Cinquenta exemplares dessa formiga foram coletadas em uma área próxima a cidade de Ponto dos Volantes e levadas para o laboratório de Controle Biológico de Insetos em Viçosa, Minas Gerais, Brasil, colocadas com álcool a $70 \%$ e enviadas ao Instituto Federal do Espirito Santo, Brasil, para identificação. Mapas foram elaborados para ilustrar a distância do ponto de coleta dos exemplares de D. lucida a sua distribuição geográfica e o levantamento da vegetação predominante do municipio de Ponto dos Volantes. Este é o primeiro relato de D. lucida no nordeste de Minas Gerais, Brasil. A maioria dos individuos de D. lucida estava morta ou quebrada, mas as possiveis causas como a destruição de seu habitat ou competição não foram determinadas. A presença desta formiga fora de sua área endêmica inicial indica a possivel presença de populações isoladas de D. lucida.

Palavras-chave: Adaptação. Formiga. Mata Atlântica. Fragmentação. Insetos.

\section{Introduction}

The giant ant, Dinoponera lucida Emery (Hymenoptera: Formicidae), is endemic of the Atlantic Rainforest Central Corridor, but the fragmentation and losses of areas of its natural habitat reduced its frequency (SAATCHI et al., 2001; RIBEIRO et al., 2009). In Brazil, D. lucida occurs in fragments of the Atlantic Rainforest of Southern Bahia and Northern Espirito Santo States, and with isolated populations in the eastern Minas Gerais and São Paulo States (ESCARRAGA et al., 2017; LENHART et al., 2013). In 2003, it was included in the official list of the Brazilian fauna threatened of extinction (MACHADO et al., 2005). Dinoponera lucida is a large, black, queenless ant with anterior inferior pronotal corner with tooth-like process, long and flagellate pilosity with white luster, smooth and shiny integument with bluish luster, scape length longer than the head width, petiole slanting obliquely on dorsal edge and total body length ranging from $27-30 \mathrm{~mm}$ (LENHART et al., 2013). Males are winged and smaller with bicolored body: head, mesosoma, and petiole brown; scape, legs and ferruginous brown gaster. Lateral ocelli protruding beyond posterior cephalic margin in dorsal view of the head; abdominal tergum VIII shaped as acute triangular; body with abundant long yellow hairs (ESCARRAGA et al., 2017). These ants are monogynous (PEIXOTO et al., 2008), and they fly and mate with workers (gamergate) near the entrance or inside the nest (MONNIN; PEETERS, 1998). Workers become gamergates as a secondary step in the dominance hierarchy (MONNIN; PEETERS, 1999; PEETERS, 2012), determined by agonistic interactions in all the Dinoponera species studied (MONNIN et al., 2003).

Dinoponera lucida has the largest number of chromosomes known in Hymenoptera (MARIANO et al., 2004), besides a significant karyotype variation: $2 \mathrm{n}=106,116,118$ and 120 (BARROS et al., 2009; SANTOS et al., 2012). This discrepancy suggests at least two lineages of this ant; one in Espirito Santo State where all the individuals have the same 
number of chromosomes, and another in southern Bahia with populations differing in the number of chromosomes (MARIANO et al., 2008). This structure may be due to the expansion behavior of this species population by migration of small groups to new areas, and increase the number of nests by colony fission. Thus, nests geographically closer are more related to each other (RESENDE et al., 2010).

The fission occurs when a reproductive female leaves the colony, with a group of workers to start a new one (ARAUJO et al., 2015; PEETERS; ITO, 2001). Nests are relatively shallow with an average of $35.1 \mathrm{~cm}$ and maximum depth of 65 $\mathrm{cm}$, with a nest density of 20-52 nests per hectare (PEIXOTO et al., 2010). As other Dinoponera species, the colony of $D$. lucida has one gamergate, workers and brood (PEIXOTO et al., 2008).

The presence of D. lucida in the municipality of Ponto dos Volantes may be a recurrence of the foraging behavior of this species and the Atlantic Forest remnants deforestation in this municipality, suggesting a possible isolation of this population. This study aim to report the occurrence of the giant ant D. lucida in the Jequitinhonha Valley, Minas Gerais State, Brazil.

\section{Material and Methods}

Fifty workers of D. lucida were found and collected in an area of about $500 \mathrm{~m}$ above the sea level within a native forest, at $5 \mathrm{~km}$ of Ponto dos Volantes city $\left(16^{\circ} 45^{\prime} 10^{\prime \prime} \mathrm{S}\right.$, 4130'14”W) at Jequitinhonha Valley, Minas Gerais State, Brazil. These specimens were placed in plastic pots and taken to the Biological Control of Insects Laboratory located at the Institute of Biotechnology Applied to Agriculture (BIOAGRO) in Viçosa, Minas Gerais State, Brazil. In the laboratory, the specimens were separated, placed in $70 \%$ alcohol and sent to the Federal Institute of Espirito Santo where they were identified through identification keys and comparison with biological collections. Maps were made using the program ArcGIS 10 to show the location of Ponto dos Volantes compared with the boundaries of the known geographic distribution of D. lucida (IBGE, 2001) and the vegetation survey of Minas Gerais State (CARVALHO et al., 2006).

\section{Results and Discussion}

The specimens were identified as Dinoponera lucida Emery (Hymenoptera: Formicidae). This is the first report of the giant ant D. lucida in the Jequitinhonha Valley of Minas Gerais State, Brazil, where the vegetation represents a transition of the Atlantic Rain Forest with the Savannah, with semi-arid climate and two well defined seasons: a dry and a rainy ones (Figure 1A). The average annual rainfall is $750 \mathrm{~mm}$ concentrated in three or four months. The distance from the Municipality of Pontos dos Volantes to the records points of D. lucida in Bahia and Espirito Santo states ranged from one hundred ninety seven to four hundred twenty eight kilometers.

Figure 1 - Vegetation map of the Municipality of Ponto dos Volantes (A), Minas Gerais State, Brazil and map of the geographic distribution of Dinoponera lucida (Hymenoptera: Formicidae: Ponerinae) (B)
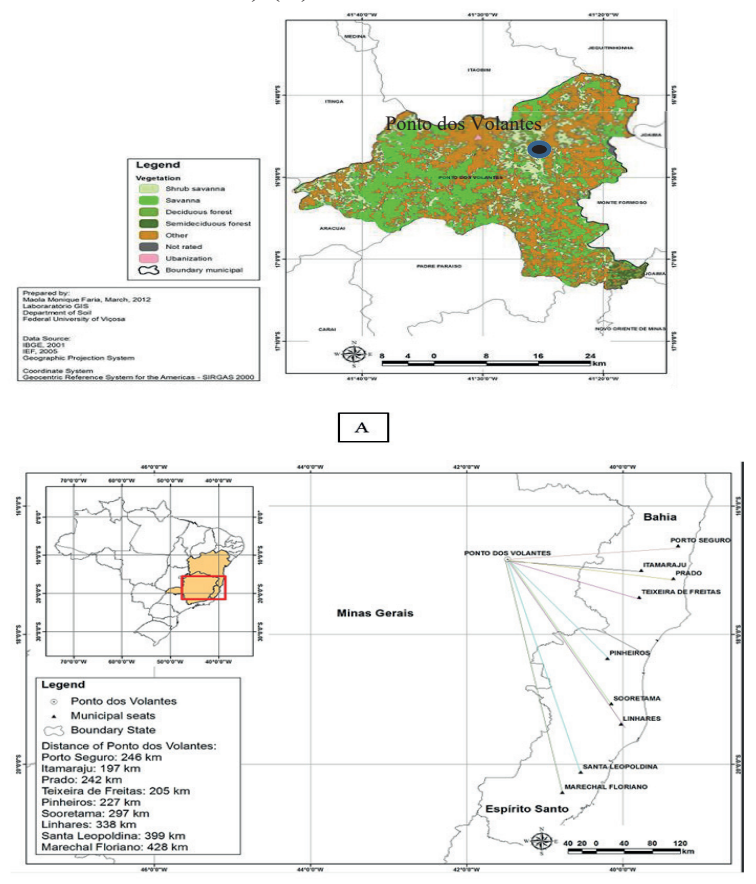

B

Fonte: Authors.

Dinoponera lucida is, mainly, restricted to Bahia and Espirito Santo States, Brazil, in forest fragments with little herbaceous ground vegetation, predominance wet tropical climate and soils generally of yellow dystrophic with mineral material in advanced weathering stage (MARIANO et al., 2008; PEIXOTO et al., 2008; PEIXOTO et al., 2010). The occurrence of D. lucida in Ponto dos Volantes, in Jequitinhonha Valley, may indicate that the range of this species includes the north of Minas Gerais State, Brazil. The area of this municipality was originally covered by the Atlantic Forest but this biome was almost extinct by human action, and nowadays restricted to the coastal region of Brazil where this ant is found. The D. lucida migratory habit, which has no wings and therefore limited dispersal ability, indicates its pre-existence in this region. The described distribution of this ant fragments of Atlantic Forest in the east coast of Brazil has a minimum distance of $197 \mathrm{~km}$ from "Ponto dos Volantes" (Figure 1B), which would make it difficult a recent immigration of D. lucida.

Most individuals of D. lucida were dead when they were collected and some of them were broken, but the possible causes such as habitat destruction or competition were not determined. Older individuals are more likely to be killed because they forage outside the colony which increases risks of death, unlike younger workers which perform tasks such as parental care in the the nest (PEIXOTO et al., 2008). 
Dinoponera lucida colonies can be attacked by Scuttle flies (Diptera: Phoridae) (DISNEY et al., 2015) and Kapala Cameron 1884 (Hymenoptera Eucharitidae) (BUYS et al., 2010). The SOS Mata Atlântica Foundation and the Instituto Nacional de Pesquisas Espaciais (INPE) pointed out that Ponto dos Volantes is among the six largest municipalities responsible for the Atlantic Forest deforestation in Brazil, with 5,398 hectares of vegetation destroyed in the last 13 years (GLOBO NATUREZA, 2018).

The natural habitat fragmentation predisposes $D$. lucida to changes by isolating inbred populations and may cause biological extinction(DE SOUZAet al., 2001). The geographic regression process of $D$. lucida is related to the destruction of its original habitat generated by the increasingly pronounced reduction of its natural occurrence areas, resulting in isolation (PAIVA, BRANDÃO, 1995; MARIANO et al., 2004). This indicates the existence of an isolated population of $D$. lucida in the Municipality of Pontos dos Volantes. The presence of this species in the list of animals threatened of extinction (ICMBio, 2018) makes it necessary to map colonies of this ant at this location. The absence of winged queens limits the gene flow, dispersion and colonization of the Dinoponera species, and therefore escaping from anthropized habitats is more difficult (PEETERS; ITO, 2001).

\section{Conclusion}

The natural range of $D$. lucida is probably larger than is known, being necessary to reformulate the official information and extend the environmental protection policies for the region.

\section{Acknowledgements}

This research was supported by Conselho Nacional de Desenvolvimento Científico e Tecnológico - CNPq, Coordenação de Aperfeiçoamento de Pessoal de Nível Superior - Capes and Fundação de Amparo à Pesquisa do Estado de Minas Gerais - FAPEMIG. To Profa. M.Sc. Isabel De Conte Carvalho de Alencar of Instituto Federal do Espírito Santo for the identification of Dinoponera lucida.

\section{References}

ARAUJO, A. et al. Poneromorfas sem rainhas - Dinoponera: aspectos ecológico-comportamentais. In DELABIE, J.H.C., et al. As formigas poneromorfas do Brasil. Ilhéus: Editus, 2015. p.237246.

BARROS, L.A.C. et al. Hsc-FA and NOR bandings on chromosomes of the giant ant Dinoponera lucida Emery, 1901 (Hymenoptera: Formicidae). Comp. Cytogenet. v.3, n.2, p.97102, 2009. doi: 10.3897/compcytogen.v3i2.16

CARVALHO, L.M.T. et al. Procedimentos para mapeamento. In SCOLFOROM, J.R.; CARVALHO, L.M.T. Mapeamento e inventário da flora e dos reflorestamentos de Minas Gerais. Lavras: Universidade Federal de Lavras, 2006. p.37-57.

DE SOUZA, O. et al. A theoretical overview of the processes determining species richness in forest fragments. Lessons from
Amazonia. In BIERREGAARD JR, R.O. et al. The ecology and conservation of a fragmented forest. New Haven: Yale University, 2001. p.13-20.

DISNEY, R.H.L.; BRAGANCA, M.A.L.; TEIXEIRA, M.C. New Species of scuttle flies (Diptera: Phoridae) associated with a ponerine ant (Hymenoptera: Formicidae) in Brazil. Sociobiology, v.62, n.3, p.124-127, 2015. doi:10.13102/sociobiology.v62i1.124127

ESCARRAGA, M.E.; LATTKE, J.E.; AZEVEDO, C.O. Discovery of the Dinoponera lucida male (Hymenoptera, Formicidae), a threatened giant ant from the Atlantic rain forest. Zootaxa, v.4347, n.1, p.128-136, 2017. doi: 10.11646/ zootaxa.4347.1.7

GLOBO NATUREZA. 2018. Disponível em: http:/g1.globo. com/natureza/noticia/2012/06/areas-inteiras-de-mata-atlanticasao-liberadas-para-desmatamento-em-mg.html. Accesso em: 26 mar. 2019.

IBGE - Instituto Brasileiro de Geografia e Estatística. 2012. Available from: http://www.ibge.gov.br/home/download/ geociencias.shtm. Accessed: 13 March 2019.

LENHART, P.A.; DASH, S.T.; MACKAY, W.P. A revision of the giant Amazonian ants of the genus Dinoponera (Hymenoptera, Formicidae). J. Hymenopt. Res. v.31, p.119-164, 2013.

MACHADO, A.B.M.; MARTINS, C.S.; DRUMMOND, G.M. Lista da fauna brasileira ameaçada de extinção: incluindo as espécies quase ameaçadas e deficientes em dados. Belo Horizonte: Fundação Biodiversitas, 2005.

MARIANO, C.S.F. et al. Dinoponera lucida Emery (Formicidae: Ponerinae): the highest number of chromosomes known in Hymenoptera. Naturwissenschaften, v.91, n.4, p.182-185, 2004. doi: 10.1007/s00114-004-0514-Z

MARIANO, C.S.F. et al. A biogeographical study of the threatened ant Dinoponera lucida Emery (Hymenoptera: Formicidae: Ponerinae) using a cytogenetic approach. Insect Conserv. Diver, v.1, n.3, p.161-168, 2008. doi: 10.1111/j.17524598.2008.00022.x

MONNIN, T.; PEETERS, C. Monogyny and regulation of worker mating in the queenless ant Dinoponera quadriceps. Anim. Behav. v.55, n.2, p.299-306, 1998. doi: 10.1006/anbe.1997.0601

MONNIN, T.; PEETERS, C. Dominance hierarchy and reproductive conflicts among subordinates in a monogynous queenless ant. Behav. Ecol. v.10, n.3, p.323-332, 1999. doi: 10.1093/beheco/10.3.323

MONNIN, T.; RATNIEKS, F.L.W.; BRANDÃO, C.F.R. Reproductive conflict in animal societies: hierarchy length increases with colony size in queenless ponerine ants. Behav. Ecol. Sociobiol. v.54, n,1. p.71-79, 2003. doi: 10.1007/s00265003-0600-9

PAIVA, R.V.S.; BRANDÃO, C.R.F. Nests, worker population, and reproductive status of workers, in the giant queenless ponerine ant Dinoponera Roger Hymenoptera Formicidae. Ethol. Ecol. Evol. v.7, n.4, p.297-312, 1995.

PEETERS, C.; ITO, F. Colony dispersal and the evolution of queen morphology in social Hymenoptera. Annu. Rev. Entomol. v.46, p.601-630, 2001. doi: 10.1146/annurev.ento.46.1.601

PEETERS, C. Convergent evolution of wingless reproductives across all subfamilies of ants, and sporadic loss of winged queens (Hymenoptera: Formicidae). Myrmecol. News. v.16, p.75-91, 2012. 
PEIXOTO, A.V. et al. Comportamento e estrutura reprodutiva da formiga Dinoponera lucida Emery (Hymenoptera, Formicidae). Rev. Bras. Entomol. v.52, n.1, p.88-94, 2008.

PEIXOTO, A.V.; CAMPIOLO, S.; DELABIE, J.H.C. Basic ecological information about the threatened ant, dinoponera lucida emery (Hymenoptera: Formicidae: Ponerinae), aiming effective long-term conservation. In TEPPER, G.H. Species diversity and extinction. [s.1.]: Nova Science Publishers, 2010. p.183-213.

RESENDE, H.C. et al. Pliocene and Pleistocene events shaping the genetic diversity within the central corridor of the Brazilian Atlantic Forest. Biol. J. Linn. Soc. v.101, n.4, p.949-960, 2010. doi: 10.1111/j.1095-8312.2010.01534.x

RIBEIRO, M.C. et al. The brazilian atlantic forest: how much is left, and how is the remaining forest distributed? Implications for conservation. Biol. Conserv., v.142, n.6, p.1141-1153, 2009. doi: 10.1016/j.biocon.2009.02.021

SAATCHI, S. et al. Examining fragmentation and loss of primary forest in the southern Bahian Atlantic forest of Brazil with radar imagery. Conserv. Biol., v.15, n.4, p.867-875, (2001). doi: 10.1046/j.1523-1739.2001.015004867.x

SANTOS, I.S. et al. Karyotype differentiation among four dinoponera (Formicidae: Ponerinae) species. Fla. Entomol. v.95, n.3, p.737-742, (2012). doi: 10.1653/024.095.0324 